\title{
Soda war heats up
}

$\mathrm{H}$ ealth organizations are comparing their battle with makers of sugary beverages to the war they once waged with big tobacco. Advocates for healthy living have run educational campaigns and called for marketing regulations and taxes on high-calorie drinks. The beverage industry, meanwhile, has accused some health departments of launching baseless attacks and has even responded in one jurisdiction with a lawsuit.

Health departments in a number of areas - including Chicago, Illinois; Seattle, Washington; and ChathamKent, Ontario - have launched public health campaigns that expose the highcalorie count in soda, sports drinks and some juices. One particularly graphic ad, sponsored by the New York City Department of Health and Mental Hygiene, shows cola being poured into a glass and turning into fat.

In response to the ads, the American Beverage Association has filed requests under freedom of information legislation with several health departments and is suing the New York City health department for allegedly holding back email correspondence that details the decisionmaking process that led to the ads.

"These campaigns are really offputting," says Chris Gindlesperger, spokesperson for the association. "They're being paid for with tax payer dollars, at a time when ... cities and states aren't able to meet their financial obligations."

By "singling out" sugary drinks, Gindlesperger argues, the campaigns simplify nutrition and weight gain and do the public a disservice. "These beverages only make up $7 \%$ of the average American's diet," he says.

But Michael Jacobson, cofounder and secretary of the board of directors of the Center for Science in the Public Interest based in Washington, DC, points out that "the $7 \%$ figure averages in a lot of little old ladies who don't drink any soda. But teenagers are actually getting $20 \%$ of their

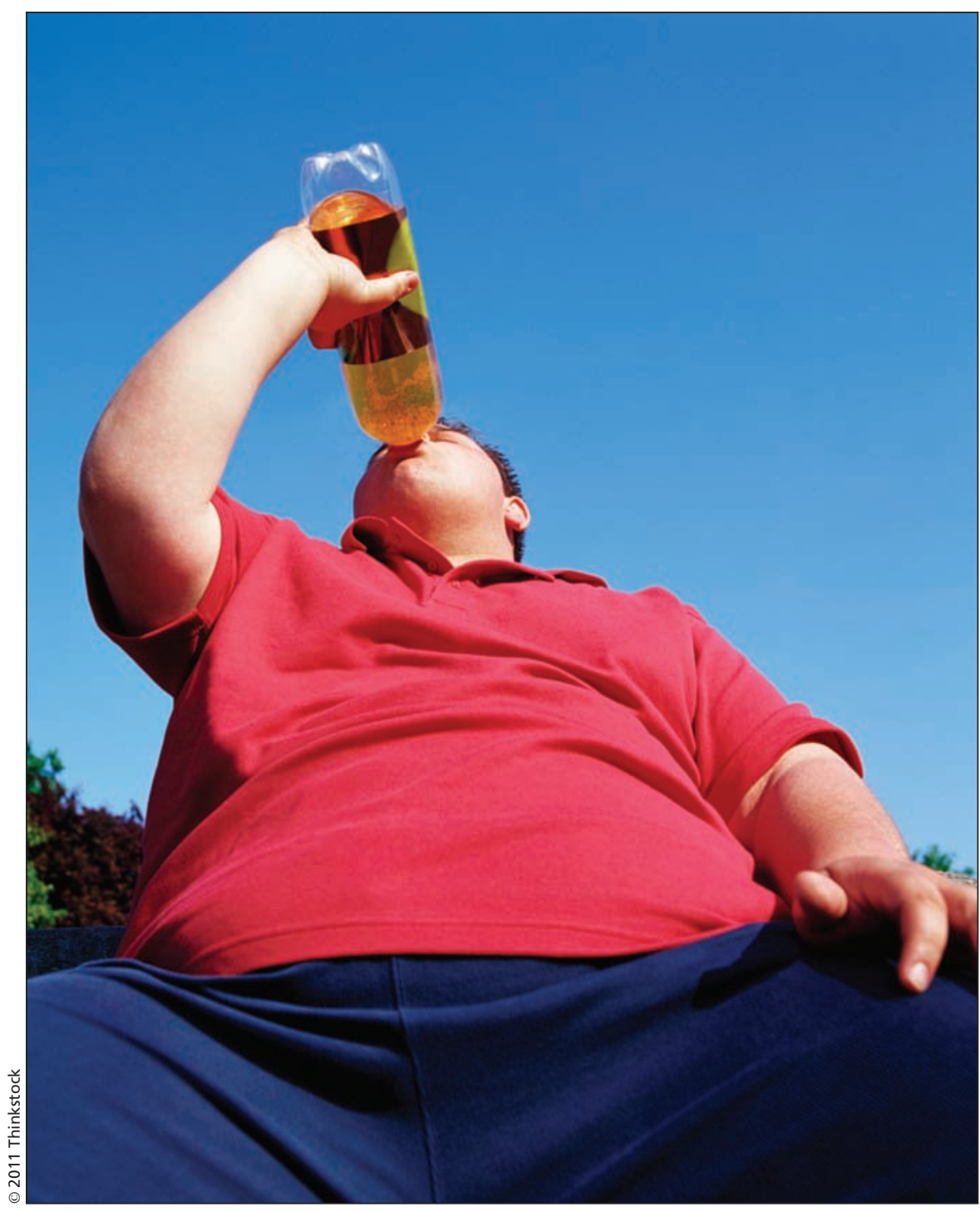

Health advocates worry that many people, teenagers in particular, are consuming too high a percentage of their calories through sugary beverages.

calories from soft drinks," he says. In California, for instance, $41 \%$ of children aged 2-11 drink at least one soda a day (http://escholarship.org/uc/item /1fj3h5cj;jsessionid=32D3B5FB5A4E FC44B0C4AF3B9FFF4132).

In addition to educational campaigns, many organizations, including the California Center for Public Health Advocacy, based in Davis, California, and the Vancouver, British Columbiabased Childhood Obesity Foundation, are calling for a tax on sugary drinks.
Harold Goldstein, executive director of the California center, says a pennyper-ounce tax could cut sugary drink consumption in the same way taxes reduced smoking, and the revenue could be funnelled into exercise programs in schools and health care. And he doesn't buy Gindlesperger's claim that a tax would have the greatest financial impact on low-income families.

"This is after decades of spending marketing dollars to target low-income communities and communities of colour 
that now have the highest obesity rates," says Goldstein, who argues PepsiCo's recent "We Inspire" campaign, featuring rapper and actress Queen Latifah among others, was specifically aimed at getting African-American mothers to consume more soda.

Gindlesperger, however, argues that industry representatives are concerned about obesity rates and have voluntarily "cut calories in schools by $88 \%$ " by replacing soft drinks with juice, water and milk. In addition, the American Beverage Association's "Clear on Calories" initiative will see the Coca-Cola Company, PepsiCo, the Dr Pepper Snapple Group and other companies move calorie counts from the back to the front of their labels. As well, Gindlesperger points out, some makers of soft drinks have voluntarily ceased marketing their high-calorie, low-nutrient beverages to children under 12 years of age.

Goldstein disagrees, noting that marketing comes in many forms. "They may not use cartoons like Camel cigarettes did, but they market in shows that kids watch, like American Idol," where judges are seen drinking a sweetened beverage.

Goldstein and Jacobson both say marketing restrictions should be mandatory rather than voluntary, and that sugary drinks shouldn't be available in areas children frequent. Goldstein adds that the drinks should be pro- hibited in all public places, including community centres and sports arenas. "At the very least, cities, counties and states shouldn't be in the business of selling sugary drinks," he says.

Until then, the billions of dollars spent on beverage marketing will give the industry a much greater advantage over campaigns of the "Rethink Your Drink" variety, which altogether consumed funding in the low millions, says Joe Prickitt, director of the Network for a Healthy California. "It's really not a level playing field for children or adults in terms of the messaging that's out there." - Wendy Glauser, Toronto, Ont.

CMAJ 2011. DOI:10.1503/cmaj.109-3965 